Kong. Res. J. 4(1) : 27-28, 2017

ISSN 2349-2694

Kongunadu Arts and Science College, Coimbatore.

\title{
PORTRAYAL OF WOMEN AND NATURE IN KINGSOLVER'S NOVEL FLIGHT BEHAVIOUR
}

\author{
Priya, E. \\ Department of English, NGM College, Pollachi. \\ E.mail: priyaeswaran8@gmail.com
}

\begin{abstract}
Literary eco -criticism is concerned with the ways that the relation between humans and nature are reflected in literary texts -the relationship of human beings with each other and with their environment. Literature has rich ecological heritage because literary history has many works on romanticism, naturalism, transcendentalism, literature of landscape and frontier literature. This paper aims to portray how Kingsolver used women and nature in her novel flight behaviour.
\end{abstract}

Keywords: Ecofeminism, American Literature, Kingsolver, Flight Behaviour.

Eco-feminism is to redefine how societies look at productivity and activity of both women and nature who have mistakenly been deemed passive, allowing for them both to be ill-used(Shiva 157).

Ecofeminism is one of the types of feminism. Ecofeminism is a combination of feminism and ecology. Feminism had little concern for the nature $\mathrm{g}$ the first and second level of feminism writers almost said little or no attention to women, animals or ecology . But, the third level of feminist connect closely with ecology. Eco feminism is relatively a new part of feminist movement. It evolved out of the political activism over the past three decades. Eco feminism explores the internationality between sexism, the domination of nature, racism, and other characteristics of social inequality.

Ecofeminism as a social and political movement points to the existence of considerable common ground between environmentalism and feminism with some currents linking deep the ecology and feminism. Eco feminists argue that a strong parallel exists between the oppression and subordination of women in families and the degradation of nature in the society. Nature in literature is however portrayed right from the classical aid and reshaped in each age. However, nature flourished and represented as the most important feature in the major writers of the Romantic period. Romanticism proclaimed the love of nature, freedom and individualism. American writers greatly emphasized the importance of nature and the primal feelings of awe, apprehension and horror felt by man on approaching the sublimity of it. They not only appreciated nature for its visual beauty, but also revered for its ability to help the urban man fine his true identity.
Nature is feminined because it is seen as possessing the same qualities as women. One could see the different dimension of women and nature. Women tend to take a secondary place in the society and also tend to be equated with nature. Thus, women and nature were inspiring and being on the losing end on both fronts and fighting the same battle against oppression. Eco feminism is a significant branch in eco critical study. Eco feminism as a social, political and academic movement focuses on the oppression of women and the exploitation of nature as being interconnected. Eco feminists argue that any attempt to liberate women will not be successful withstand equal attempt to liberate nature.

Many feminists make a verbal connection between elimination0 of women and domination of nature. Ecofeminism is based on certain fundamental claims that pointing the existence of important connections between the oppression of women and nature. It is essential to understand the nature of these connections in order to understand the oppression of women and nature.

Kingsolver is a American novelist, essayist and poet Her works often focus on social justice, biodiversity and interaction between humans and their environment. Many of her works display her thorough knowledge of biology and ecology.

This paper focus on Kingsolver' s novel Flight Behaviour. It deals with the possible effects of global warming on the Monarch butterflies and the significance of growing awareness of climate change impact on people's life. In this novel Kingsolver shows how environmental awareness significantly changed protagonists life positively. Dellarobia 
Turnbow is the central character. She is well observant but poorly educated young mother living in the rural community of Feather town, Tennessee . She is a sheep farmers wife. She faces a hard life staying in that sheep farm looking after they children and the household. Dellarobia's transformation in her life came when she encounter the view of million of butterflies imagining on tree leaves. Their usual migratory route has been disrupted, and what looks to be a stunningly beautiful view is really an ominous sign or ecological disaster. The sudden pain and cold of Appalachian winter could be the demise of this delicate species. They have to move away from that mountain looking for a warmer place. She was quite able to relate the environmental disaster of landslide and flood which occurred in Mexico which is the habitat ed these butterflies. She realised the fact that "when you clear-but a mountain it can cause a landslide"(234).

Dr. Byron , an entomologist, arrive to study those monarch butterflies and tries to find out the season behind their sudden and unexpected visit to southern Appalachian mountain. He unfolds the mystery of mass extinction of these colourful species because of drastic climate change. Dellarobia environmental consciousness makes her save dying butterflies. "What was the use of saving a world that has no soul left in it. Continents without butterflies and sea without coral reefs"(438). These lines shows the people's anthropocentric attitude towards nature.

This novel shows the environmental awareness.. especially the female protagonist Dellarobia's environmental consciousness and personal growth as an independent woman. She participated in contemporary environmental protection and preservation act. Her personal development comes through her transformation into an environmentally aware individual. In this novel, environmental awareness and global responsibility plays vital role in Dellarobia's life. Dellarobia's journey from a distracted, unhappy farm life to become an environment conscious person tells the story of self-consciousness towards natural environment.

\section{REFERENCE}

Kingsolver, Barbara, 2012. Flight Behaviour. New York: Harper Collins. 